\title{
Hydration of a calcium sulfoaluminate cement blended with zincite
}

\section{Gwenn Le Saoût}

Professor, LMGC, IMT Mines Ales, Univ Montpellier, CNRS, Ales, France (corresponding author: gwenn.le-saout@mines-ales.fr) (Orcid:0000-0002-2761-0584)

\section{Dominique Lafon-Pham}

Professor, EuroMov Digital Health in Motion, IMT Mines Ales, Univ Montpellier, Ales, France

\section{Jean Claude Roux}

Research Engineer, Centre des Matériaux de l'École des mines d'Alès

(C2MA), IMT Mines Alès, University of Montpellier, Alès, France

A calcium sulfoaluminate (CSA) cement has been characterised by X-ray diffraction and energy-dispersive X-ray spectroscopy analysis. Selective extraction methods have been used to improve detection limits for identification and quantitative measurements. Perovskites are present in the cement in the form of brownmillerite and a phase with the following average chemical composition $\mathrm{Ca}_{1.95} \mathrm{Mg}_{0.05} \mathrm{Al}_{0.29} \mathrm{Ti}_{0.39} \mathrm{Fe}_{1.03} \mathrm{Si}_{0.22} \mathrm{O}_{5.18}$. The zincite is known as a strong retarder for ordinary Portland cement (OPC), and its effect on the hydration of CSA cement was investigated using isothermal calorimetry, thermal analysis and X-ray diffraction. The low $\mathrm{pH}$ of the pore solution in the CSA cement compared to the OPC considerably reduces the solubility of zincite and, at an early age of hydration, zincite behaves as a filler in the CSA cement.

\section{Introduction}

The first patent for a calcium sulfoaluminate (CSA) cement was taken out in 1935 (Établissements Poliet \& Chausson, 1935). CSA cements were mainly used as expansive binders in the 1950s (Klein and Troxell, 1958) before their development for structural applications by the China Building Material Academy in the 1970s (Zhang et al., 1999). CSA cements have many specific properties compared to Portland cements, such as fast setting, rapid hardening and shrinkage reduction. This special cement used alone or in combination with calcium sulfates and Portland cement has found applications such as airport runways and road patching, self-levelling mortars, tile adhesive grouts and so on (Zhang et al., 1999). This is also a promising alternative to Portland cement with a low carbon dioxide $\left(\mathrm{CO}_{2}\right)$ footprint, owing to the difference in energy used to produce CSA cements (lower kiln temperatures and energy at the mill to grind) and the lower mass of carbon dioxide emitted during the clinkering reaction (Gartner, 2004). The main raw materials used for making CSA cements are bauxite, limestone, clay and gypsum, and this leads to a wide range of mineralogical composition different from that of Portland cements (Wang and $\mathrm{Su}, 1994)$. CSA cements may be classified according to the content of ye'elimite (Aranda and De la Torre, 2013; Odler, 2000)

- calcium sulfoaluminate clinkers which contain ye'elimite or kleinite, Klein's salt or tetracalcium trialuminate sulfate $\left(\mathrm{C}_{4} \mathrm{~A}_{3} \overline{\mathrm{S}}\right)$ with a content varying between 50 and $90 \mathrm{mass}^{\circ} \%$

- belite CSA clinkers containing belite $\left(\mathrm{C}_{2} \mathrm{~S}\right)(40-50$ mass $\%)$ as the main phase and a lower amount of ye'elimite (20-30 mass $\%)$

- alite CSA clinkers containing alite and ye'elimite.
In this study, a commercial CSA cement was used. CSA clinkers were usually co-grinded with 15 to 25 mass $\%$ of calcium sulfate to optimise strength development and volume changes (Winnefeld and Barlag, 2009). The first part of this study was dedicated to the characterisation of the anhydrous CSA cement as only few studies are available concerning the characterisation of CSA cements (García-Maté et al., 2015).

Zinc oxide $(\mathrm{ZnO})$ can get into Portland cement in different ways. It may be introduced from zinc present in the clinker (Bolio-Arceo and Glasser, 1998), from industrial waste stabilised using cementitious materials (Fernández Olmo et al., 2001) or from galvanised steel reinforcements (Belaïd et al., 2001). It can be used as a rebar corrosion inhibitor (De Rincón et al., 2002), for its photocatalytic properties or for the purpose of self-cleaning materials (Senff et al., 2014). However, zincite is particularly known as a strong hydration retarder for Portland cement (Arliguie and Grandet, 1985; Ataie et al., 2015) and alkali-activated slag (Garg and White, 2017) and this can restrict the possible applications of zincite. The mechanism of retardation in these systems is still controversial. The formation of a zinc hydroxide $\left(\mathrm{Zn}(\mathrm{OH})_{2}\right)$ phase on the cement particle surfaces preventing further dissolution, as first proposed by Arliguie and Grandet (1985), was not experimentally observed and the retardation was subsequently explained by the depletion of calcium in solution by the formation of a calcium zincate phase (Garg and White, 2017) or by nucleation and growth poisoning of calcium silicate hydrate $(\mathrm{C}-\mathrm{S}-\mathrm{H})$ (Ataie et al., 2015). Although many studies have been carried out on the effect of zinc oxide on the hydration of Portland cements, the aim of the present study is to investigate the effect of zincite on early-age hydration of a commercial CSA cement. 


\section{Materials and methods}

\section{Materials}

The chemical composition of the CSA cement is given in Table 1. Zincite ( $\mathrm{ZnO}$ extra $\left.\mathrm{S}, \mathrm{ZnO}>99.9 \operatorname{mass}^{\circ} \%, d_{50}=6 \mu \mathrm{m}\right)$ was from Silar. Quartz from Sifraco $\left(d_{50}=11 \mu \mathrm{m}\right)$ was used as a chemically inert material for the calorimetric experiments. In order to check the effect of particle size, the quartz was also milled to $d_{50}=7 \mu \mathrm{m}$ in a McCrone micronising mill. Mixtures of the CSA cement with 10 mass $\%$ of the zincite or quartz were prepared by co-grinding the materials by hand in an agate mortar for $15 \mathrm{~min}$.

Table 1. Mineralogical and chemical compositions of the CSA cement

\begin{tabular}{|c|c|c|c|}
\hline Oxides & $\begin{array}{c}\text { Mass } \\
\%\end{array}$ & Phases & $\begin{array}{c}\text { Mass } \\
\%\end{array}$ \\
\hline Sodium oxide $\left(\mathrm{Na}_{2} \mathrm{O}\right)$ & 0.02 & Yee'limite & $31 \cdot 4$ \\
\hline Magnesium oxide (MgO) & $1 \cdot 27$ & Belite & $21 \cdot 2$ \\
\hline Aluminium oxide $\left(\mathrm{Al}_{2} \mathrm{O}_{3}\right)$ & $19 \cdot 1$ & Anhydrite & $18 \cdot 3$ \\
\hline Silicon dioxide $\left(\mathrm{SiO}_{2}\right)$ & $8 \cdot 42$ & Gypsum & $2 \cdot 9$ \\
\hline Phosphorus pentoxide $\left(\mathrm{P}_{2} \mathrm{O}_{5}\right)$ & 0.08 & Perovskite & $11 \cdot 3$ \\
\hline Sulfur trioxide $\left(\mathrm{SO}_{3}\right)$ & $15 \cdot 2$ & Ferrite & $5 \cdot 4$ \\
\hline Potassium oxide $\left(\mathrm{K}_{2} \mathrm{O}\right)$ & 0.08 & Calcite & $3 \cdot 5$ \\
\hline Calcium oxide $(\mathrm{CaO})$ & 44.9 & Dolomite & $0 \cdot 7$ \\
\hline Titanium dioxide $\left(\mathrm{TiO}_{2}\right)$ & 0.76 & Periclase & 0.6 \\
\hline Manganese oxide (MnO) & 0.04 & Merwinite & 1.9 \\
\hline Iron (III) oxide $\left(\mathrm{Fe}_{2} \mathrm{O}_{3}\right)$ & $6 \cdot 94$ & Magnesite & $1 \cdot 5$ \\
\hline $\mathrm{LOI}^{\mathrm{a}}$ & $3 \cdot 3$ & Magnesioferrite & $0 \cdot 8$ \\
\hline$d_{10}: \mu m^{b}$ & 2 & Magnetite & $0 \cdot 2$ \\
\hline$d_{50}: \mu \mathrm{m}$ & 7 & Quartz & $0 \cdot 2$ \\
\hline$d_{90}: \mu \mathrm{m}$ & 19 & & \\
\hline Density: $\mathrm{g} / \mathrm{cm}^{3}$ & 2.99 & & \\
\hline
\end{tabular}

Chemical analysis by XRF

aLoss on ignition (LOI) measured up to $950^{\circ} \mathrm{C}$ by TGA

barticle size determined by laser granulometry
The pastes were formulated to have a water-to-cement ratio of $0 \cdot 70$. Samples consisting of $50 \mathrm{~g}$ of binder and the appropriate amount of water were mixed twice for $90 \mathrm{~s}$ with a high-shear blender (except for internal mixing in conduction calorimetry experiments).

\section{Methods}

The particle size distribution was measured by laser diffraction spectrometer LS 13320 Beckman Coulter using the wet method with isopropyl alcohol for cement and deionised water for quartz and zincite as a dispersion medium. Ultrasonic treatment was used to improve the cement dispersion.

In order to analyse the mineralogical composition, X-ray diffraction (XRD) was performed with a diffractometer, the Bruker D8 Advance. Powder samples were analysed using an incident beam angle $(\mathrm{Cu} \mathrm{K} \alpha, \lambda=0 \cdot 154 \mathrm{~nm})$ varying between 5 and $75^{\circ}$. X'Pert High Score Plus software (version 2.1) was used to process diffraction patterns and Rietveld analysis. The Inorganic Crystal Structure Database ( ICSD) codes used for the Rietveld refinement are given in Table 2. For the in situ XRD analysis, the paste was cast into a sample holder positioned in a temperature-controlled stage from Mesicon at $25^{\circ} \mathrm{C}$ and covered by a Kapton polyimide film to prevent evaporation. An external standard zinc oxide (G-factor approach) was used to quantify the X-ray amorphous and crystalline non-quantified parts according to the method presented by Jansen et al. (2011) and applied to an ordinary Portland system. The mass attenuation coefficients of the samples were calculated using data from X-ray fluorescence analysis (Table 1)

For thermogravimetric analysis (TGA), plastic bottles of volume $12 \mathrm{ml}$ were completely filled with the fresh paste; the

Table 2. References of the different phases used for Rietveld analysis

\begin{tabular}{|c|c|c|c|c|}
\hline Phase & Formula & Crystal system & ICSD & Reference \\
\hline \multirow[t]{2}{*}{ Ye'elimite } & \multirow[t]{2}{*}{$C_{4} A_{3} \bar{S}$} & Orthorhombic & 80361 & Calos et al. (1995) \\
\hline & & Cubic & 9560 & Saalfeld and Depmeier (1972) \\
\hline Belite & $\mathrm{C}_{2} \mathrm{~S}-\alpha_{\mathrm{H}}^{\prime}$ & Orthorhombic & 81097 & Mumme et al. (1995) \\
\hline Anhydrite & $C \bar{S}$ & Orthorhombic & 16382 & Kirfel and Will (1990) \\
\hline Gypsum & $\mathrm{CS} \mathrm{H}_{2}$ & Monoclinic & 151692 & De la Torre et al. (2004) \\
\hline Perovskite & $\mathrm{CT}$ & Cubic & 31865 & Sasaki et al. (1987) \\
\hline Ferrite & $\mathrm{C}_{4} \mathrm{AF}$ & Orthorhombic & 98827 & Redhammer et al. (2004) \\
\hline Calcite & $\bar{C} \bar{C}$ & Hexagonal & 79674 & Wartchow (1989) \\
\hline Dolomite & $C M \bar{C}_{2}$ & Hexagonal & 31335 & Effenberger et al. (1983) \\
\hline Periclase & $\mathrm{M}$ & Cubic & 104844 & Taylor (1984) \\
\hline Merwinite & $\mathrm{C}_{3} \mathrm{MS}_{2}$ & Monoclinic & 26002 & Moore and Araki (1972) \\
\hline Magnesite & $M \bar{C}$ & Hexagonal & 63663 & Göttlicher and Vegas (1988) \\
\hline Magnesioferrite & MF & Cubic & 24229 & Barth and Posnjak (1932) \\
\hline Magnetite & $\mathrm{Fe}_{3} \mathrm{O}_{4}$ & Cubic & 29129 & Sasaki (1997) \\
\hline Ettringite & $\mathrm{C}_{6} \mathrm{AS}_{3} \mathrm{H}_{32}$ & Hexagonal & 155395 & Goetz-Neunhoeffer and Neubauer (2006) \\
\hline Gibbsite & $\mathrm{AH}_{3}$ & Monoclinic & 27698 & Saafeld and Wedde (1974) \\
\hline
\end{tabular}


bottles were sealed and stored at $25^{\circ} \mathrm{C}$. Hydration was stopped by immersing small pieces (around $2-3 \mathrm{~mm}^{3}$ ) for $30 \mathrm{~min}$ in isopropanol and rinsing twice with diethyl ether. TGA (Netzsch STA 449F5) was performed using about $50 \mathrm{mg}$ of powder at a heating rate of $20^{\circ} \mathrm{C} / \mathrm{min}$ under nitrogen between 30 and $950^{\circ} \mathrm{C}$.

A conduction calorimeter (Tam Air, Thermometric AB, Sweden) operating at $25^{\circ} \mathrm{C}$ was used to determine the hydration heat flow. About $5 \mathrm{~g}$ of paste were weighed into sealed glass flasks and transferred into the calorimeter within $3 \mathrm{~min}$. In order to study the very early hydration reactions (before $1 \mathrm{~h}$ ), admix ampoules described by Wadsö (2005) were also used to enable internal mixing.

For the microscopic investigations of anhydrous samples, powder was impregnated using a low-viscosity epoxy resin and polished down to $0 \cdot 25 \mu \mathrm{m}$ using diamond pastes. The polished sections obtained were further coated with carbon $(\sim 5 \mathrm{~nm})$ and examined using a Quanta 200 FEG scanning electron microscope (SEM) from FEI coupled to an Oxford Xmax N $80 \mathrm{~mm}^{2}$ energy-dispersive X-ray spectroscopy (EDX) analyser. The EDX analyses were used to determine the elemental compositions of the phase assemblage. The analyses were carried out using an acceleration voltage of $15 \mathrm{kV}$ to ensure a good compromise between spatial resolution and adequate excitation of the $\mathrm{FeK}_{\alpha}$ peak.

In order to improve the characterisation of the anhydrous cement, two different selective dissolution methods were used. In the first method, an aqueous solution of potassium hydroxide and sucrose was used to produce a residue rich in belite (Lejbina, 1969). In the second one, the silicate phases were removed in a solution of salicylic acid in methanol (SAM) (Hjorth and Lauren, 1971). In addition, ye'elimite, anhydrite and gypsum phases were dissolved in a $5 \%$ sodium carbonate $\left(\mathrm{Na}_{2} \mathrm{CO}_{3}\right)$ solution (Wang, 2010) to obtain a residue with a high amount of perovskites. This method was modified to prevent precipitation of calcium carbonate $\left(\mathrm{CaCO}_{3}\right)$ by washing the filtered suspension with $6 \%$ acetic acid (AA) solution. The filter paper and contents were placed in an oven at $105^{\circ} \mathrm{C}$ until a constant weight was reached.

Thermodynamic modelling was carried out using the Gibbs free energy minimisation software GEMS v3.4 (Kulik et al., 2013) with the thermodynamic database from PSI-GEMS (Hummel et al., 2002) and the Cemdata $18 \cdot 1$ database specific to cement (Lothenbach et al., 2019). Modelling was conducted in a similar manner as described before for the hydration of CSA cements (Le Saoût et al., 2013; Winnefeld and Lothenbach, 2010). By combining experimental data based on the XRD-Rietveld analysis, which describes the dissolution of the cement phases as a function of time, with a thermodynamic equilibrium model, which assumes equilibrium between the solution and the hydrates, the amount and nature of hydrates formed can be described as a function of time.

The $\mathrm{pH}$ of the interstitial solution at early age was determined with a $\mathrm{pH}$ meter combined with an electrode, the Jenway Ion Meter 3345. The interstitial solution was obtained after mixing cement paste for $7 \mathrm{~min}$, then the paste was centrifuged for $10 \mathrm{~min}$ at $10000 \mathrm{r} / \mathrm{min}$ and filtered using $0.45 \mathrm{~mm}$ filter syringe.

\section{Results and discussion}

\section{Characterisation of the CSA cement}

The main phases observed in the experimental diffraction pattern (Figure 1) are the orthorhombic ye'elimite $\mathrm{C}_{4} \mathrm{~A}_{3} \overline{\mathrm{S}}$ with a small amount of the pseudo cubic form, belite $\beta$ and $\alpha_{\mathrm{H}^{-}}^{\prime} \mathrm{C}_{2} \mathrm{~S}$ and perovskites from the CSA clinker. Anhydrite II $\mathrm{C} \overline{\mathrm{S}}$ is also present as a mineral addition. The molar ratio of gypsum and anhydrite to ye'elimite leads to a value of about 2.9 that corresponds to a self-stressing cement (Winnefeld and Barlag, 2010). The amount of belite obtained by Rietveld refinement (21 $\mathrm{mass}^{\%} \%$ ) is close to the value calculated from the SAM extraction method $(23+/-2 \operatorname{mass} \%)$. The SAMsodium carbonate-AA extraction method leads to an amount of perovskite, ferrite, magnesite, magnesioferrite, dolomite, quartz and periclase of around $15 \mathrm{mass} \%$, in good agreement with the Rietveld analysis (15 mass $\%$ ). The magnetite does not dissolve but is extracted by the bar magnet and it can be considered that the dissolution rate of dolomite in the presence of acetic acid is quite low compared to calcite and aragonite (Toyama and Terakado, 2015). According to the present result, the method seems quantitative but should be repeated with a large range of CSA cements. The perovskite family has crystal structures related to the mineral perovskite $\mathrm{CT}$. Ferrite phase $\mathrm{Ca}_{2}\left(\mathrm{Al}_{x} \mathrm{Fe}_{1-x}\right)_{2} \mathrm{O}_{5}$ is usually present in CSA clinker and its structure is derived from that of perovskite by the substitution of $\mathrm{Al}$ and $\mathrm{Fe}$ for $\mathrm{Ti}$, together with ordered omission of oxygen atoms, which causes one-half of the octahedral sheets in perovskite to be replaced by tetrahedral chains (Taylor, 1997). To improve Rietveld refinement, it is necessary to add a perovskite phase CT (Álvarez-Pinazo et al., 2012). The titanium dioxide is present in the bauxite used as a raw material in the manufacturing process of CSA clinker. The peaks associated with this cubic phase are confirmed in the XRD pattern of the CSA after the extraction of the main phases (Figure 1(c)). EDX analysis on a polished section of the CSA (Figure 2) was used to determine the chemical composition of each phase of the anhydrous cement (Table 3). The CSA cement after extraction revealed an average composition of ferrite $\mathrm{Ca}_{1 \cdot 99} \mathrm{Al}_{0 \cdot 39} \mathrm{Si}_{0 \cdot 10} \mathrm{Fe}_{1 \cdot 35} \mathrm{Ti}_{0 \cdot 08} \mathrm{Mg}_{0 \cdot 07} \mathrm{O}_{5 \cdot 00}$ not far from the composition of the brownmillerite series $\mathrm{Ca}_{2}\left(\mathrm{Fe}_{2-x} \mathrm{Al}_{x}\right) \mathrm{O}_{5}$. However, the average composition of perovskite $\mathrm{Ca}_{1.95} \mathrm{Mg}_{0.05} \mathrm{Al}_{0.29} \mathrm{Ti}_{0.39} \mathrm{Fe}_{1 \cdot 03} \mathrm{Si}_{0.22} \mathrm{O}_{5 \cdot 18}$ is far from the perovskite $\mathrm{Ca}_{2} \mathrm{Ti}_{2} \mathrm{O}_{4}$ composition with, in some grains, perovskite lamellae with a high amount of $\mathrm{Ti}$ on the scale of a few 


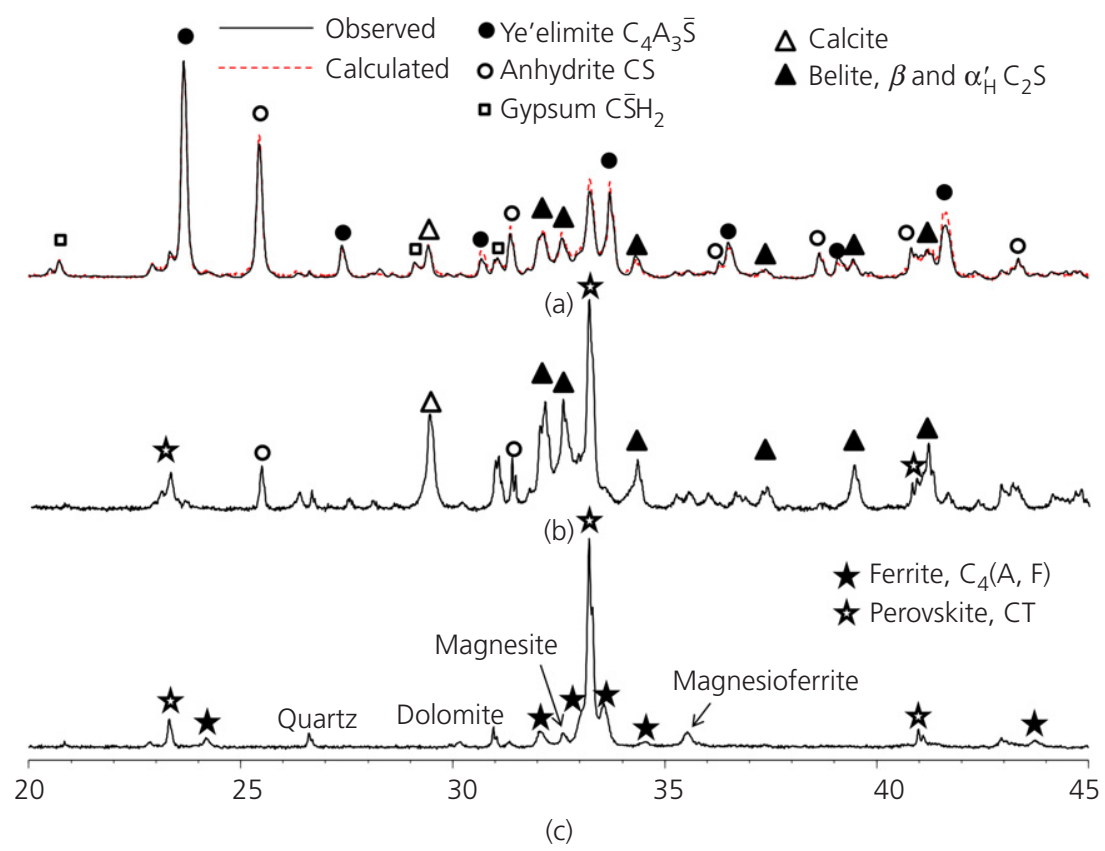

Angle $2 \theta$ : CuK $\alpha$ : degrees

Figure 1. Diffraction patterns of (a) the CSA cement as received; (b) after potassium hydroxide (KOH)/sucrose extraction; and (c) after SAM and sodium carbonate extraction. The dashed curve in part (a) represents the Rietveld refinement

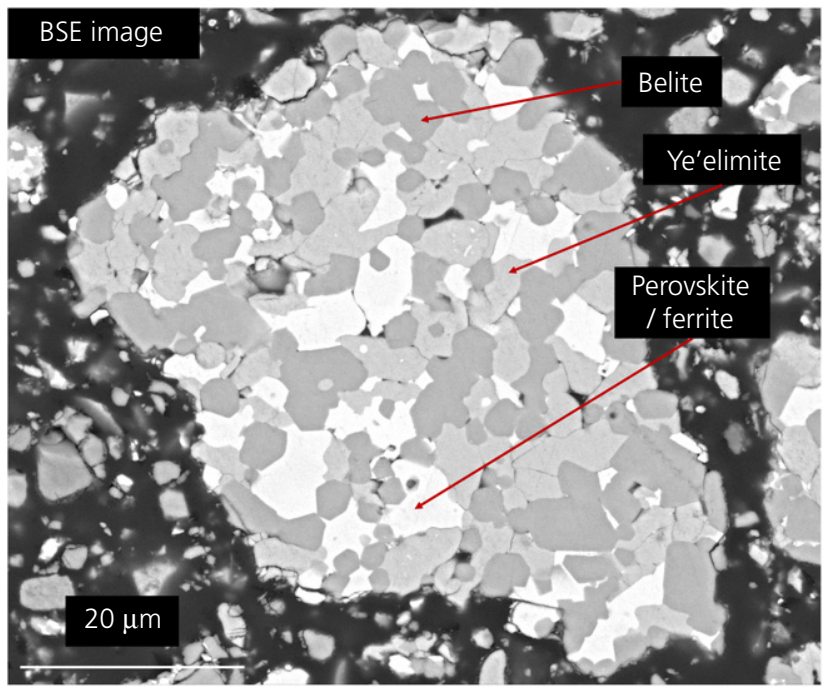

Figure 2. Back-scattering image of the CSA cement (BSE, backscattered electron)

micrometres (Le Saoût et al., 2019). These compositions were similar to those observed by Gloter et al. (2000) for the ferrite/perovskite phases in a calcium aluminate cement.

In order to confirm the amount of perovskites in the sample, a set of 266 images was processed by means of the Aphelion imaging software (Aphelion Dev, version 4.4.0). The whole process is composed of several steps, which use the following Aphelion groups of function: Gaussian filtering, segmentation in order to subtract from the surface the porosity filled by epoxy resin, morphological filter and segmentation to detect perovskite phases (Figure 3). According to the Delesse principle (Delesse, 1848), it can be assumed that the fractional area of a section plane taken up by perovskite phases is an estimate of the volume fraction. The mean value of the volume per cent of perovskites phases (ferrite and perovskite) deduced by image analysis has a value of $11 \pm 2 \mathrm{vol} \%$. This value can be compared to the sum of volume per cent of perovskite and ferrite deduced by XRD and equal to $12.7 \mathrm{vol} \%$ as Rietveld refinement permits both the weight and volume fraction to be obtained (Le Saoût et al., 2011). Good agreement of the results can be observed, confirming the amount of perovskites in the cement.

\section{Hydration of the CSA cement}

Figure 4 shows the thermal power as a function of time for the CSA cement. The curves are similar to that observed in a calcium sulfate-ye'elimite system (Winnefeld and Barlag, 2010) except for the kinetic, which depends on many parameters such as the presence of alkalis or minor phases as $\mathrm{C}_{12} \mathrm{~A}_{7}$ (Zajac et al., 2019). The first peak observed with in situ experiments (Figure 4(b)) occurs when the water is added and can be assigned to wetting and early hydration process. After an induction period of about $2 \mathrm{~h}$, two heat flow maxima occur at 3 and $5 \mathrm{~h}$. Unlike in Portland cement where the addition of 
Table 3. Atomic ratios for some phases in CSA calculated from energy dispersive spectroscopy

\begin{tabular}{|c|c|c|c|c|c|c|c|c|c|}
\hline Phases/Formulae & $\mathrm{Na}$ & $\mathrm{Ca}$ & Mg & $\mathrm{Fe}$ & Al & $\mathrm{Si}$ & S & $\mathrm{Ti}$ & 0 \\
\hline Ye'elimite & $<1$ & $402(5)$ & $<1$ & 28(4) & $560(7)$ & $7(2)$ & $100(4)$ & $<1$ & 1600 \\
\hline $\mathrm{Ca}_{4.02} \mathrm{Al}_{5.60} \mathrm{Fe}_{0.28} \mathrm{Si}_{0.07} \mathrm{~S}_{1.01} \mathrm{O}_{16}$ & 402 & & & 595 & & & 100 & & \\
\hline Belite & $<1$ & 192(6) & $<1$ & $1(1)$ & $7(1)$ & $89(6)$ & $5(3)$ & $<1$ & 400 \\
\hline $\mathrm{Ca}_{1.92} \mathrm{Al}_{0.07} \mathrm{Si}_{0.89} \mathrm{~S}_{0.05} \mathrm{O}_{4}$ & 192 & & & 102 & & & & & \\
\hline Ferrite & $<1$ & $198(1)$ & $7(1)$ & 133(1) & $39(2)$ & 10(1) & $<1$ & $8(1)$ & 500 \\
\hline $\mathrm{Ca}_{2.05} \mathrm{Mg}_{0.07} \mathrm{Al}_{0.39} \mathrm{Fe}_{1.33} \mathrm{Si}_{0.10} \mathrm{Ti}_{0.08} \mathrm{O}_{5}$ & 205 & & & 190 & & & & & \\
\hline Perovskite & $<1$ & $195(5)$ & $5(1)$ & $103(6)$ & 29(4) & 22(3) & $<1$ & $39(5)$ & $\begin{array}{r}518(7) \\
518\end{array}$ \\
\hline $\mathrm{Ca}_{1.95} \mathrm{Mg}_{0.05} \mathrm{Al}_{0.29} \mathrm{Ti}_{0.39} \mathrm{Fe}_{1.03} \mathrm{Si}_{0.22} \mathrm{O}_{5.18}$ & 200 & & & 193 & & & & & 518 \\
\hline
\end{tabular}

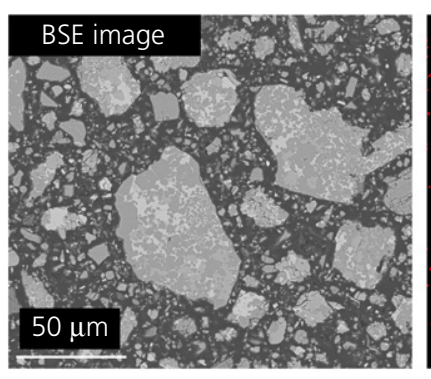

(a)

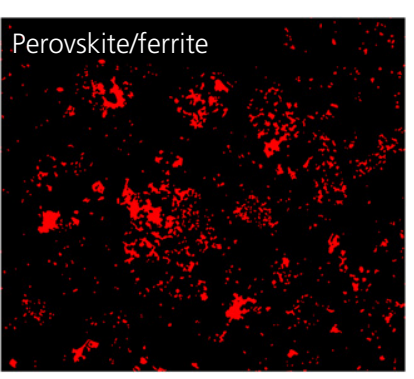

(b)
Figure 3. Back-scattering image of (a) the CSA cement and (b) the perovskite and ferrite phases after image analysis

10 mass $\%$ of zincite extends the induction period (no peak of hydration is observed in the calorimetric curve up to $80 \mathrm{~h}$, experiment not shown), the addition of zincite shortened the induction period of about $10 \mathrm{~min}$. A similar effect is observed when the finely ground quartz is added to the CSA cement, which indicates that the slight acceleration is due to the additional surface provided for the nucleation and growth of hydration products (Lothenbach et al., 2008).

Figure 5 shows the amount of phases deduced from in situ XRD Rietveld analysis as a function of hydration time and measured heat flow. As previously observed, the solubility of calcium sulfates influences the initial period of hydration (Allevi et al., 2016; Winnefeld and Barlag, 2009). The gypsum, which is more soluble than anhydrite, completely dissolves after $3 \mathrm{~h}$, followed by the dissolution of anhydrite up to $8 \mathrm{~h}$ after the depletion of gypsum. In parallel, the dissolution of the ye'elimite phase occurs at the same time as the precipitation of the ettringite and $\mathrm{AH}_{3}$ according to the reaction (Figure 6)

$$
\mathrm{C}_{4} \mathrm{~A}_{3} \overline{\mathrm{S}}+2 \mathrm{C} \overline{\mathrm{S}} \mathrm{H}_{x}+(38-2 x) \mathrm{H} \rightarrow \mathrm{C}_{6} \mathrm{~A}_{3} \mathrm{H}_{32}+2 \mathrm{AH}_{3}
$$

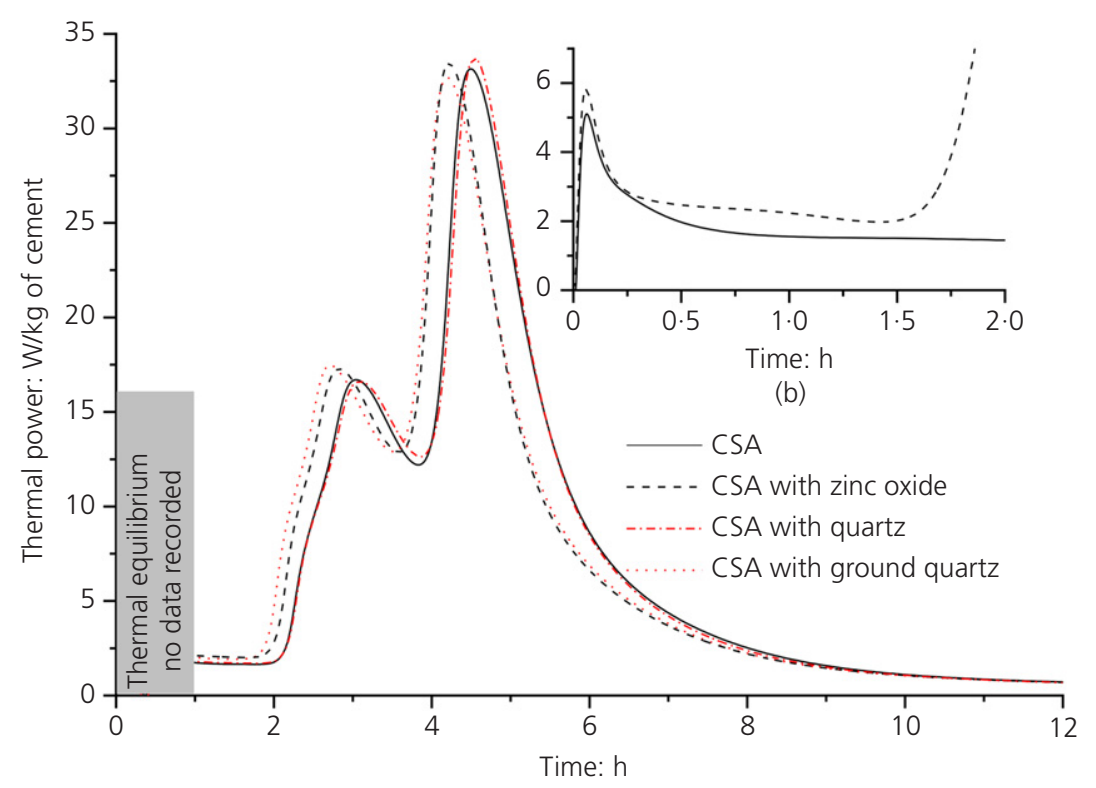

(a)

Figure 4. Heat flow development of mixtures with CSA cement and different fillers as a function of time: (a) between 0 and $12 \mathrm{~h}$ using external mixing; (b) (inset) between 0 and $2 \mathrm{~h}$ using internal mixing 


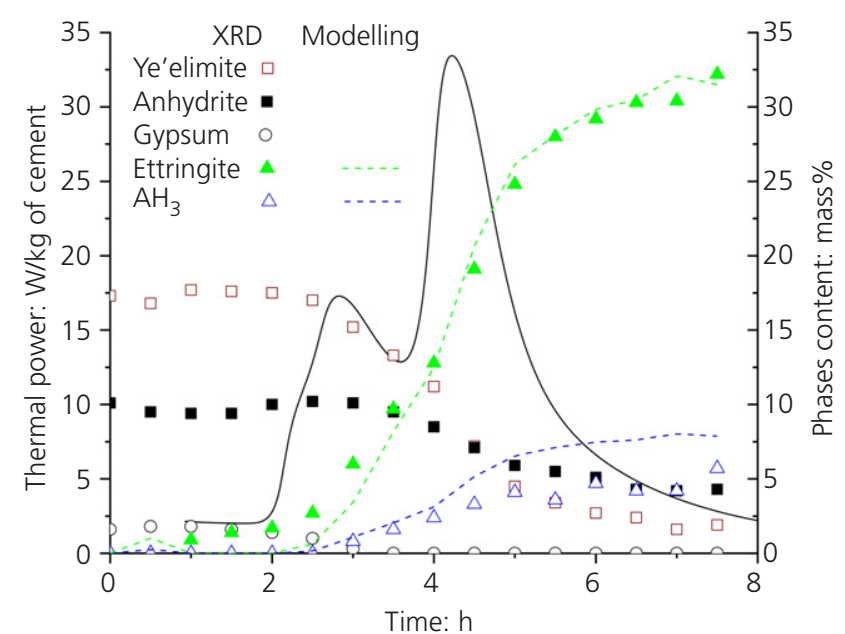

Figure 5. Phases content calculated from in situ XRD experiments (dotted points) and heat flow development (continuous lines) of CSA cement blended with zincite between 0 and $8 \mathrm{~h}$. Dotted lines refer to the results of thermodynamic modelling

Some broad reflections of $\mathrm{AH}_{3}$ were observed by XRD but, as previously reported (Le Saoût et al., 2018), $\mathrm{AH}_{3}$ is not well crystallised and is difficult to characterise using XRD, especially with an in situ analysis where the conditions lead to a lower signal-to-noise ratio. The precipitation of $\mathrm{AH}_{3}$ with the ettringite is better highlighted by TGA experiments (Figure 7). The other phases are not represented as they do not show significant changes with hydration time up to $1 \mathrm{~d}$. By combining experimental data based on the Rietveld XRD data for the ye'elimite and sulfate phases as a function of time with a thermodynamic equilibrium model, the nature and amount of hydrates formed as a function of time can be deduced. Thermodynamic modelling shows the formation of ettringite and $\mathrm{AH}_{3}$ in microcrystalline form, in agreement with experimental data. The calculated amount of ettringite (dotted line in Figure 5) corresponds to the amount deduced by XRD and the difference for $\mathrm{AH}_{3}$ can be explained by the X-ray amorphous part of the $\mathrm{AH}_{3}$.

The retarding effect of zincite observed in the case of the hydration of OPC is not found for the CSA cement. For the CSA cement, alkali concentrations are much lower compared to OPC, resulting in a lower $\mathrm{pH}$ in the pore solution during the first hours of hydration (Le Saoût et al., 2013; Winnefeld and Barlag, 2010). The $\mathrm{pH}$ values measured for the CSA and the OPC cements after $7 \mathrm{~min}$ of hydration (respectively, $10 \cdot 4$ and 13.2) are reported in Figure 8 with the solubility of zincite as a function of $\mathrm{pH}$. The solubility $(S)$ of zincite in $\mathrm{mol} / \mathrm{l}$ is defined as the sum of the concentrations of soluble species $\mathrm{Zn}^{2+}, \mathrm{Zn}(\mathrm{OH})_{2}, \mathrm{Zn}(\mathrm{OH})_{3}{ }^{-}$and $\mathrm{Zn}(\mathrm{OH})_{4}{ }^{2-}$. Based on the thermodynamic data provided by GEMS and Wang et al. (2001) (see Table 4), the mole distributions of the different species in equilibrium with zincite at various $\mathrm{pH}$ values are compared in Figure 8. The Gibbs energy formation is similar in both databases, except for zinc hydroxide, which explains the differences between the mole distributions and solubility. Unlike OPC where zincite dissolves and leads to the formation $\mathrm{Zn}(\mathrm{OH})_{4}{ }^{2-}$ that poisons nucleation and growth mechanisms, zincite is practically not soluble in the pore solution of the CSA cement at early age. Zincite can be considered practically inert in the CSA cement at early age and acts as a filler.

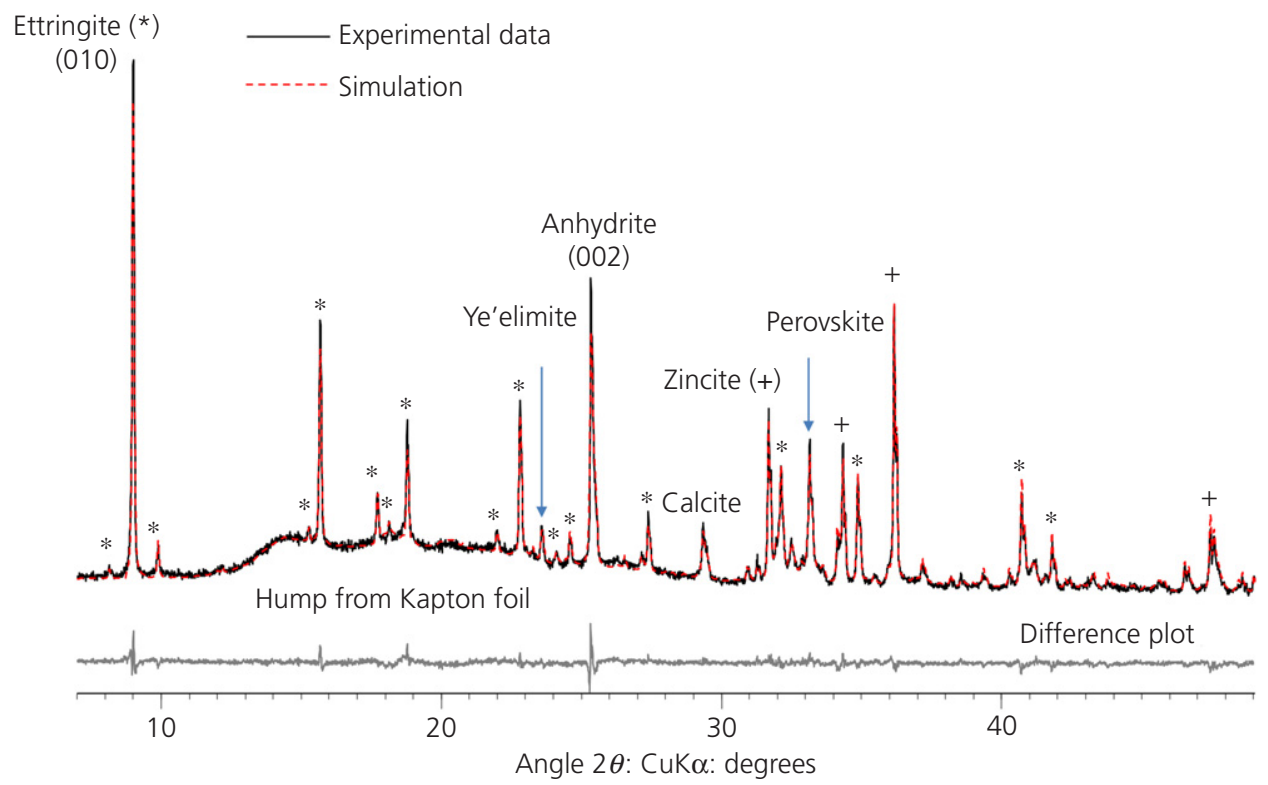

Figure 6. Refined pattern of the in situ XRD experiment of the CSA cement at $25^{\circ} \mathrm{C}$ and $w / C=0.7$ after $8 \mathrm{~h}$ of hydration 


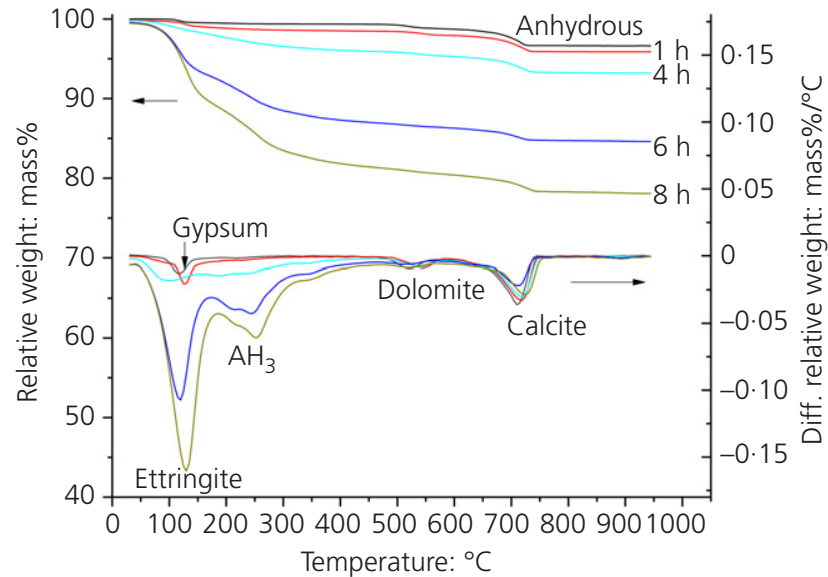

Figure 7. Weight loss recorded by TGA (top of the figure) and differential thermogravimetry data (bottom of the figure) of CSA cement between 0 and $8 \mathrm{~h}$. A full-colour version of this figure can be found on the ICE Virtual Library (www.icevirtuallibrary.com)

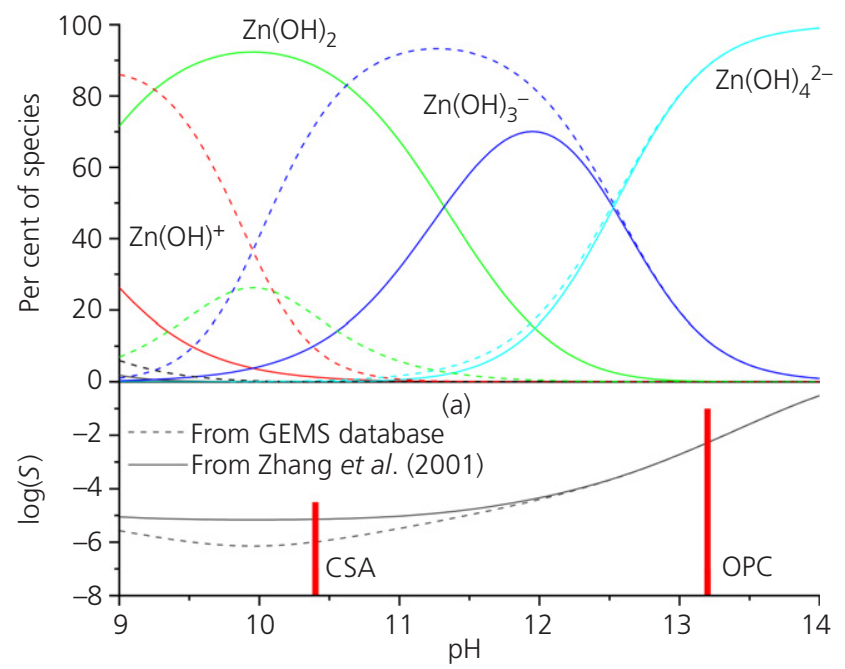

(b)

Figure 8. Zincite solubility (a) and soluble species (b) between $\mathrm{pH}$ 9 and 14 at $T=298.15 \mathrm{~K}$ according to the thermodynamic data reported in Zhang and Muhammed (2001) (dotted line) and in the GEMS database (solid line). Thick vertical lines indicate the $\mathrm{pH}$ of the pore solution after 7 min of hydration in CSA and OPC cements

\section{Conclusion}

The phase assemblage of a CSA cement has been investigated with a special focus on the perovskite phases. A modified selective extraction method highlighting the perovskite phases is presented to improve Rietveld refinement and facilitate EDX measurements. Perovskites are present in the cement in the form of brownmillerite and a phase with an average composition of $\mathrm{Ca}_{1 \cdot 95} \mathrm{Mg}_{0 \cdot 05} \mathrm{Al}_{0 \cdot 29} \mathrm{Ti}_{0 \cdot 39} \mathrm{Fe}_{1 \cdot 03} \mathrm{Si}_{0 \cdot 22} \mathrm{O}_{5 \cdot 18}$.
Table 4. The standard Gibbs energy of formation $\Delta_{\mathrm{f}} G_{0}$ of some species in the system $\mathrm{Zn}(\mathrm{II})-\mathrm{H}_{2} \mathrm{O}$ at $298.15 \mathrm{~K}$ given by the GEMS database and the paper review (Wang et al., 2001)

\begin{tabular}{llc} 
& \multicolumn{2}{c}{$\mathbf{\Delta}_{\mathbf{f}} \mathbf{G}_{\mathbf{0}}: \mathbf{k J} / \mathbf{m o l}$} \\
\cline { 2 - 3 } Species & GEMS & Zhang and Muhammed (2001) \\
\hline $\mathrm{H}_{2} \mathrm{O}$ & $-237 \cdot 18$ & $-237 \cdot 14 \pm 0 \cdot 04$ \\
$\mathrm{OH}^{-}$ & $-157 \cdot 27$ & $-157 \cdot 22 \pm 0 \cdot 07$ \\
$\mathrm{Zn}^{2+}$ & $-147 \cdot 3$ & $-147 \cdot 2 \pm 0 \cdot 4$ \\
$\mathrm{Zincite}$ & $-320 \cdot 5$ & $-320 \cdot 5 \pm 0 \cdot 4$ \\
$\mathrm{Zn}(\mathrm{OH})^{+}$ & $-339 \cdot 7$ & $-342 \pm 3$ \\
$\mathrm{Zn}(\mathrm{OH})_{2}^{0}$ & $-519 \cdot 3$ & $-528 \pm 2$ \\
$\mathrm{Zn}(\mathrm{OH})_{3}^{-}$ & -700 & $-698 \pm 2$ \\
$\mathrm{Zn}(\mathrm{OH})_{4}^{2-}$ & -865 & $-860 \pm 3$ \\
\hline
\end{tabular}

The hydration of the CSA cement has been followed at early age where the ye'elimite reacts with calcium sulfate to produce ettringite and $\mathrm{AH}_{3}$. The zincite behaves as a filler in the CSA cement and does not present a strong retardant effect as in OPC, which may result in greater potential use.

\section{Acknowledgements}

The authors would like to acknowledge Alain Diaz for sample preparation for the SEM experiments and Vicat for supplying the cement.

\section{REFERENCES}

Allevi S, Marchi M, Scotti F, Bertini S and Cosentino C (2016) Hydration of calcium sulphoaluminate clinker with additions of different calcium sulphate sources. Materials and Structures 49(1-2): 453-466.

Álvarez-Pinazo G, Cuesta A, García-Maté M et al. (2012) Rietveld quantitative phase analysis of yeelimite-containing cements. Cement and Concrete Research 42(7): 960-971.

Aranda MAG and De la Torre AG (2013) Sulfoaluminate cement. In Eco-Efficient Concrete (Pacheco-Torgal F, Jalali S, Labrincha J and John VM (eds)). Woodhead Publishing, Cambridge, UK, pp. $488-522$.

Arliguie G and Grandet J (1985) Etude par calorimétrie de l'hydratation du ciment Portland en présence de zinc. Cement and Concrete Research 15(5): 825-832 (in French).

Ataie FF, Juenger MCG, Taylor-Lange SC and Riding KA (2015) Comparison of the retarding mechanisms of zinc oxide and sucrose on cement hydration and interactions with supplementary cementitious materials. Cement and Concrete Research 72: $128-136$.

Barth TFW and Posnjak E (1932) Spinel structures: with and without variate atom equipoints. Zeitschrift Für KristallographieCrystalline Materials 82: 325-341.

Belaïd F, Arliguie G and François R (2001) Porous structure of the ITZ around galvanized and ordinary steel reinforcements. Cement and Concrete Research 31(11): 1561-1566.

Bolio-Arceo $\mathrm{H}$ and Glasser FP (1998) Zinc oxide in cement clinkering: part 1. Systems $\mathrm{CaO}-\mathrm{ZnO}-\mathrm{Al}_{2} \mathrm{O}_{3}$ and $\mathrm{CaO}-\mathrm{ZnO}-\mathrm{Fe}_{2} \mathrm{O}_{3}$. Advances in Cement Research 10(1): 25-32, https://doi.org/10.1680/ adcr.1998.10.1.25.

Calos NJ, Kennard CH, Whittaker AK and Davis RL (1995) Structure of calcium aluminate sulfate $\mathrm{Ca}_{4} \mathrm{Al}_{6} \mathrm{O}_{16} \mathrm{~S}$. Journal of Solid State Chemistry 119(1): 1-7. 
De la Torre ÁG, López-Olmo MG, Álvarez-Rua C, García-Granda S and Aranda MAG (2004) Structure and microstructure of gypsum and its relevance to Rietveld quantitative phase analyses. Powder Diffraction 19(3): 240-246.

Delesse A (1848) Procédé mécanique pour déterminer la composition des roches. Annales des Mines 13(4): 379-388 (in French).

De Rincón OT, Pérez O, Paredes E et al. (2002) Long-term performance of $\mathrm{ZnO}$ as a rebar corrosion inhibitor. Cement and Concrete Composites 24(1): 79-87.

Effenberger H, Kirfel A and Will G (1983) Untersuchungen zur Elektronendichteverteilung im Dolomit CaMg $\left(\mathrm{CO}_{3}\right)_{2}$. Tschermaks Mineralogische Und Petrographische Mitteilungen 31(1-2): 151-164 (in German).

Établissements Poliet \& Chausson (1935) Nouveau ciment et son procédé de fabrication. French Patent FR 780.747, May (in French).

Fernández Olmo I, Chacon E and Irabien A (2001) Influence of lead, zinc, iron (III) and chromium (III) oxides on the setting time and strength development of Portland cement. Cement and Concrete Research 31(8): 1213-1219.

García-Maté M, Santacruz I, Cuesta A et al. (2015) Amorphous determination in calcium sulfoaluminate materials by external and internal methods. Advances in Cement Research 27(7): 417-423, https://doi.org/10.1680/adcr.14.00026.

Garg N and White CE (2017) Mechanism of zinc oxide retardation in alkali-activated materials: an in situ X-ray pair distribution function investigation. Journal of Materials Chemistry A 5(23): 11794-11804.

Gartner E (2004) Industrially interesting approaches to 'low- $\mathrm{CO}_{2}$ ' cements. Cement and Concrete Research 34(9): 1489-1498.

Gloter A, Ingrin J, Bouchet D, Scrivener K and Colliex C (2000) TEM evidence of perovskite-brownmillerite coexistence in the $\mathrm{Ca}$ $\left(\mathrm{Al}_{\mathrm{x}} \mathrm{Fe}_{1-\mathrm{x}}\right) \mathrm{O}_{2.5}$ system with minor amounts of titanium and silicon. Physics and Chemistry of Minerals 27(7): 504-513.

Goetz-Neunhoeffer F and Neubauer J (2006) Refined ettringite $\left(\mathrm{Ca}_{6} \mathrm{Al}_{2}\left(\mathrm{SO}_{4}\right)_{3}(\mathrm{OH})_{12} 26 \mathrm{H}_{2} \mathrm{O}\right)$ structure for quantitative X-ray diffraction analysis. Powder Diffraction 21(1): 4-11.

Göttlicher S and Vegas A (1988) Electron-density distribution in magnesite $\left(\mathrm{MgCO}_{3}\right)$. Acta Crystallographica Section B: Structural Science, Crystal Engineering and Materials 44(4): 362-367.

Gualtieri AF (2000) Accuracy of XRPD QPA using the combined Rietveld-RIR method. Journal of Applied Crystallography 33(2): 267-278.

Hjorth L and Lauren KG (1971) Belite in Portland cement. Cement and Concrete Research 1(1): 27-40.

Hummel W, Berner U, Curti E, Pearson FJ and Thoenen T (2002) Nagra/PSI chemical thermodynamic data base 01/01 Radiochimica Acta 90(9-11): 805-813.

Jansen D, Goetz-Neunhoeffer F, Stabler C and Neubauer J (2011) A remastered external standard method applied to the quantification of early OPC hydration. Cement and Concrete Research 41(6): 602-608.

Kirfel A and Will AG (1990) Charge density in anhydrite, $\mathrm{CaSO}_{4}$, from $\mathrm{X}$-ray and neutron diffraction measurements. Acta Crystallographica Section B 36(12): 2881-2890.

Klein A and Troxell GE (1958) Studies of a calcium sulfoaluminate admixtures for expansive cements. ASTM Proceedings 58: 986-1008.

Kulik DA, Wagner T, Dmytrieva SV et al. (2013) GEM-Selektor geochemical modeling package: revised algorithm and GEMS3K numerical kernel for coupled simulation codes. Computational Geosciences 17(1): 1-24.

Lejbina LP (1969) Quantitative analysis of tricalcium aluminate and tetracalcium aluminoferrite in the same sample. Ogneupory SSSR 34: $52-56$.

Le Saoût G, Kocaba V and Scrivener K (2011) Application of the Rietveld method to the analysis of anhydrous cement. Cement and Concrete Research 41(2): 133-148.
Le Saoût G, Lothenbach B, Hori A, Higuchi T and Winnefeld F (2013) Hydration of Portland cement with additions of calcium sulfoaluminates. Cement and Concrete Research 43: 81-94.

Le Saoût G, Lothenbach B, Taquet P, Fryda H and Winnefeld F (2018) Hydration of calcium aluminate cement blended with anhydrite. Advances in Cement Research 30(1): 24-36, https://doi.org/10.1680/ jadcr.17.00045.

Le Saoût G, Idir R and Roux JC (2019) Characterization of perovskites in a calcium sulfo aluminate cement. In 14th International Congress for Applied Mineralogy (ICAM 2019) (Galgolev S (ed.)). Springer Nature Switzerland, Cham, Switzerland.

Lothenbach B, Le Saoût G, Gallucci E and Scrivener K (2008) Influence of limestone on the hydration of Portland cements. Cement and Concrete Research 38(6): 848-860.

Lothenbach B, Kulik DA, Matschei T et al. (2019) Cemdata18: a chemical thermodynamic database for hydrated Portland cements and alkali-activated materials. Cement and Concrete Research 115: 472-506

Moore PB and Araki T (1972) Atomic arrangement of merwinite, $\mathrm{Ca}_{3} \mathrm{Mg}\left[\mathrm{SiO}_{4}\right]_{2}$, an unusal dense-packed structure of geophysical interest. American Mineralogist 57(9-10): 1355-1374.

Mumme WG, Hill RJ, Bushnell-Wye G and Segnit ER (1995) Rietveld crystal structure refinements, crystal chemistry and calculated powder diffraction data for the polymorphs of dicalcium silicate and related phases. Neues Jahrbuch Für Mineralogie Abhandlungen 169(1): $35-68$.

Odler I (2000) Special Inorganic Cements: Modern Concrete Technology 8. E \& FN Spon, London, UK.

Redhammer GJ, Tippelt G, Roth G and Amthauer G (2004) Structural variations in the brownmillerite series $\mathrm{Ca}_{2}(\mathrm{Fe}, \mathrm{Al}) \mathrm{O}_{5}$ : single-crystal $\mathrm{X}$-ray diffraction at $25^{\circ} \mathrm{C}$ and high temperature $\mathrm{X}$-ray powder diffraction $\left(25^{\circ} \mathrm{C}<\mathrm{T}<1000^{\circ} \mathrm{C}\right)$. American Mineralogist 89(2-3): 405-420.

Saalfeld H and Depmeier W (1972) Silicon-free compounds with sodalite structure. Crystal Research and Technology 7(1-3): 229-233.

Saafeld H and Wedde M (1974) Strukturen des Hydrargillits und der Zwischenstufen beim Entwaessern. Zeitschrift für Kristallographie 139S(1-2): 129-135 (in German).

Sasaki S (1997) Radial distribution of electron density in magnetite, $\mathrm{Fe}_{3} \mathrm{O}_{4}$. Acta Crystallographica Section B: Structural Science 53(5): 762-766

Sasaki S, Prewitt CT and Bass JD (1987) Orthorhombic perovskite $\mathrm{CaTiO}_{3}$ and $\mathrm{CdTiO}_{3}$ : structure and space group. Acta Crystallographica Section C: Structural Chemistry 43(9): 1668-1674.

Senff L, Tobaldi DM, Lemes-Rachadel P, Labrincha JA and Hotza D (2014) The influence of $\mathrm{TiO}_{2}$ and $\mathrm{ZnO}$ powder mixtures on photocatalytic activity and rheological behaviour of cement pastes. Construction and Building Materials 65: 191-200.

Taylor D (1984) Thermal expansion data. I. Binary oxides with the sodium chloride and wurtzite structure, MO. Transactions and Journal of the British Ceramic Society 83: 5-9.

Taylor HFW (1997) Cement Chemistry. Thomas Telford, London, UK.

Toyama K and Terakado Y (2015) Differential dissolution technique for the geochemical separation of the calcite and dolomite of dolomitic limestones. Geochemical Journal 49(5): 567-570.

Wadsö L (2005) Applications of an eight-channel isothermal conduction calorimeter for cement hydration studies. Cement International 5(5): 94-101.

Wang J (2010) Hydration Mechanism of Cements Based on Low-CO Clinkers Containing Belite, Ye'elimite and Calcium Alumino-Ferrite. $\mathrm{PhD}$ dissertation, University of Lille, Lille, France.

Wang Y and Su M (1994) The third cement series in China. World Cement (August): 6-10. 
Wartchow R (1989) Datensammlung nach der 'learnt profile'-Methode (LP) für Calcit und Vergleich mit der 'background peak background'.-Methode (BPB). Zeitschrift für Kristallographie 300-303 (in German).

Winnefeld F and Barlag S (2009) Influence of calcium sulfate and calcium hydroxide on the hydration of calcium sulfoaluminate clinker. ZKG International 12: 42-53.

Winnefeld F and Barlag S (2010) Calorimetric and thermogravimetric study on the influence of calcium sulfate on the hydration of ye'elimite. Journal of Thermal Analysis and Calorimetry 101(3): 949-957.

Winnefeld F and Lothenbach B (2010) Hydration of calcium sulfoaluminate cements - experimental findings and thermodynamic modeling. Cement and Concrete Research 40(8): 1239-1247.

Zajac M, Skocek J, Bullerjahn F et al. (2019) Early hydration of ye'elimite: insights from thermodynamic modelling. Cement and Concrete Research 120: 152-163.

Wang M, Zhang Y and Muhammed M (2001) Critical evaluation of thermodynamics of complex formation of metal ions in aqueous solutions VI. Hydrolysis and hydroxo-complexes of $\mathrm{Zn}^{2+}$ at 298.15 K. Hydrometallurgy 60(3): 215-236.

Zhang L, Su M and Wang Y (1999) Development of the use of sulfo- and ferroaluminate cements in China. Advances in Cement Research 11(1): 15-21, https://doi.org/10.1680/ adcr.1999.11.1.15. 